\title{
Extracts of feverfew inhibit mitogen-induced human peripheral blood mononuclear cell proliferation and cytokine mediated
} responses: a cytotoxic effect

\author{
L. A. J. O'NEILL, MARILYN L. BARRETT \& G. P. LEWIS \\ Department of Pharmacology, Hunterian Institute, Royal College of Surgeons, London WC2A 3PN
}

Feverfew has been used since antiquity to treat inflammatory conditions. Extracts of the herb were found to inhibit mitogen-induced tritiated thymidine $\left(\left[{ }^{3} \mathrm{H}\right]-\mathrm{TdR}\right)$ uptake by human peripheral blood mononuclear cells (PBMC), interleukin 2 (IL-2)-induced [ $\left.{ }^{3} \mathrm{H}\right]-$ TdR uptake by lymphoblasts and $\mathrm{PGE}_{2}$ release by interleukin 1 (IL-1)-stimulated synovial cells. Parthenolide, a major secondary metabolite from the herb also blocked $\left[{ }^{3} \mathrm{H}\right]$-TdR uptake by mitogen-induced PBMC. However, both crude extracts and parthenolide proved cytotoxic to mitogen-induced PBMC and IL-1 stimulated synovial cells, the cytotoxic effect being functionally indistinguishable from the inhibitory effects. The pharmacological properties of feverfew may thus be due to cytotoxicity, although the time course of the events described in this paper is different from those where feverfew appears to have more specific inhibitory effects.

Keywords feverfew rheumatoid arthritis cytokines

\section{Introduction}

The basis for the ability of feverfew (Tanacetum parthenium) to give relief to migraine and arthritis sufferers has come under recent investigation, with reports indicating phospholipase $\mathbf{A}_{2}$ inhibition (Collier et al., 1980; Makheja \& Bailey, 1982), cyclo-oxygenase and lipoxygenase inhibition (Capasso, 1986) and inhibition of granule secretion in platelets (Heptinstall et al. , 1985), as possible effects of crude extracts from the herb. In rheumatoid arthritis (RA), the prominence of lymphocytes and macrophages in the synovium has led to speculation that cell-cell interactions and, in particular, the activity of cytokines, may have a pathogenic role (Lewis \& Gordon, 1984). We have consequently examined the effect of extracts from the herb and a major secondary metabolite of the herb, parthenolide, on mitogeninduced proliferation of human peripheral blood mononuclear cells (PBMC) and the effect of extracts on the actions of interleukin 1 (IL-1) and interleukin 2 (IL-2).

\section{Methods}

Organic and aqueous extracts were prepared by suspending $1 \mathrm{~g}$ of microfine powdered leaf (supplied by R. L. Scherer Ltd, Swindon), in $50 \mathrm{ml}$ phosphate buffer saline (PBS) at $\mathrm{pH} 7.4$, or chloroform: methanol $(3: 7 \mathrm{v} / \mathrm{v})$. Supernatants were decanted and filtered, giving the aqueous extract a final concentration equivalent to $20 \mathrm{mg}$ of powdered leaf to $1 \mathrm{ml}$. Organic extracts were evaporated to dryness and re-suspended in $50 \mathrm{ml}$ PBS, giving a final concentration similar to that of the aqueous extract. In some experiments, the parthenolide fraction was purified from the crude extracts by thin layer chromatography (t.l.c.), and identified using spray reagents specific for the sesquiterpene lactone family of compounds (Pickman et al., 1980), of which parthenolide is a member. Results with the parthenolide fraction are not reported separately here since it was found to have the same properties as crystalline parthenolide. This substance, which was supplied by Dr P. Hylands 
(Kings College, Chelsea), was also used as a standard for t.l.c. analysis.

Human peripheral blood mononuclear cells were separated from heparinized blood of normal volunteers as previously described (Gordon \& Lewis, 1984). Aliquots of cell suspension containing $2 \times 10^{5}$ viable cells were dispensed into flat-bottomed microtitre wells for assessment of lymphocyte proliferative response by the measurement of incorporation of tritiated thymidine $\left(\left[{ }^{3} \mathrm{H}\right]-\mathrm{TdR}\right)$, as induced by phytohemagglutinin (PHA), concanavalin A (ConA) or phorbol myristic acid (PMA). The cells were incubated for $72 \mathrm{~h}$ with the extracts or mitogens, $\left[{ }^{3} \mathrm{H}\right]$-TdR being added after $48 \mathrm{~h}$. IL-2-induced proliferation was assessed using PHA-induced lymphoblasts as previously reported (Gordon \& Lewis, 1984). The effects of extracts were also examined directly on IL-1-induced $\mathrm{PGE}_{2}$ production by adherent synovial cells. Incubations were for $48 \mathrm{~h}$, with IL-1 (Genzyme) at a concentration of $1.2 \mathrm{u} \mathrm{ml}^{-1}$.

Possible cytotoxic effects of extracts and parthenolide were studied by measuring the percentage of cells exhibiting trypan blue exclusion and by measuring lactate dehydrogenase (LDH) release using a diagnostic kit supplied by Sigma. $\mathrm{LDH}$ release was expressed as a percentage of the total release obtained after lysing the cells by freezing and thawing.

\section{Results}

Both extracts and parthenolide could inhibit mitogen-induced proliferation of PBMC and IL2-induced proliferation of lymphoblasts. $\mathrm{ED}_{50}$ values are given in Table 1.

Extracts also inhibited IL-1 $\left(1.2 \mathrm{u} \mathrm{ml}^{-1}\right)$-induced $\mathrm{PGE}_{2}$ production by synovial cells from control values of $300 \mathrm{ng} \mathrm{PGE}_{2} / 10^{6}$ cells. $\mathrm{ED}_{50}$ values were $0.1 \pm 0.02 \mathrm{mg} \mathrm{ml}^{-1}$ and $0.2 \pm 0.04 \mathrm{mg} \mathrm{ml}^{-1}$ for organic and aqueous extracts respectively.
However, in cytoxicity studies, extracts and parthenolide were found to be cytotoxic to mitogen-stimulated PBMC in both a dose(Figure 1) and a time-dependent manner (Table 2).

Although little cytotoxicity was evident when the highest concentrations were in contact with the mononuclear cells for $24 \mathrm{~h}$, cytotoxicity was significant at $48 \mathrm{~h}$ and increased further at $72 \mathrm{~h}$ contact.

It was found that the $\mathrm{LD}_{50}$ s for cytotoxicity at 3 days, measured by $\% \mathrm{LDH}$ release and trypan blue exclusion, corresponded closely to $\mathrm{ED}_{50} \mathrm{~s}$ for inhibition of proliferation of PBMC as shown for organic extract of feverfew in Figure 1. Similar results were obtained for the aqueous extract and for parthenolide.

Extracts proved more cytotoxic to synovial cells, with $\mathrm{LD}_{50} \mathrm{~s}$ of $0.5 \pm 0.1 \mathrm{mg} \mathrm{ml}^{-1}$ and 0.25 $\pm 0.1 \mathrm{mg} \mathrm{ml}^{-1}$ for organic and aqueous extracts respectively at $48 \mathrm{~h}$. The similarity between $\mathrm{LD}_{50} \mathrm{~s}$ for cytotoxicity and $\mathrm{ED}_{50} \mathrm{~s}$ for $\mathrm{PGE}_{2}$ production by the cells was also evident at this time.

\section{Discussion}

The results therefore indicated that feverfew extracts contained a material which could inhibit mitogen-stimulated proliferation of PBMC, including that induced by IL-2, as well as IL-1 induced $\mathrm{PGE}_{2}$ production by synovial cells. However, extracts and parthenolide proved to be cytotoxic to mitogen-treated PBMC and to synovial cells in a similar concentration range. The toxicity was evident whether measured by the number of cells excluding trypan blue stain or by the release of $\mathrm{LDH}$ in a cell population. This strongly suggested that all the effects on the mononuclear cells measured after $72 \mathrm{~h}$, and on the synovial cells after $48 \mathrm{~h}$ contact time, were due to cytotoxicity.

In contrast to our findings, other groups have indicated specific biological targets for feverfew

Table $1 \mathrm{ED}_{50}$ values for inhibition by feverfew extracts and parthenolide of mitogen-induced $\left[{ }^{3} \mathrm{H}\right]-\mathrm{TdR}$ incorporation by PBMC and of IL-2-induced $\left[{ }^{3} \mathrm{H}\right]-\mathrm{TdR}$ incorporation by lymphoblasts

\begin{tabular}{lccc}
\hline & Organic $\left(\mathrm{mg} \mathrm{ml}^{-1}\right)$ & Aqueous $\left(\mathrm{mg} \mathrm{ml}^{-1}\right)$ & Parthenolide $(\mu M)$ \\
\hline Sub-optimal PHA $\left(0.03 \mu \mathrm{g} \mathrm{ml}^{-1}\right)$ & $0.06 \pm 0.01$ & $0.06 \pm 0.02$ & $0.012 \pm 0.001$ \\
Optimal PHA $\left(1 \mu \mathrm{gl}^{-1}\right)$ & $0.1 \pm 0.02$ & $0.16 \pm 0.03$ & not measured \\
ConA $\left(10 \mu \mathrm{g} \mathrm{ml}^{-1}\right)$ & $0.2 \pm 0.01$ & $0.06 \pm 0.02$ & $"$ " \\
PMA $\left(1 \mu \mathrm{g} \mathrm{ml}^{-1}\right)$ & $0.02 \pm 0.0$ & $0.06 \pm 0.01$ & $"$ \\
IL-2 $\left(200 \mathrm{ng} \mathrm{ml}^{-1}\right)$ & $0.04 \pm 0.02$ & $0.03 \pm 0.01$ & $"$ \\
\hline
\end{tabular}

Values correspond to a $50 \%$ inhibition, where $1 \mathrm{mg} \mathrm{ml}^{-1}$ corresponds to that amount of extract resulting from the extraction of $1 \mathrm{mg}$ of leaf into $1 \mathrm{ml}$ of medium used. Results are from five replicate cultures ( \pm s.e. mean) following $72 \mathrm{~h}$ incubation periods, pulsing after $48 \mathrm{~h}$ 


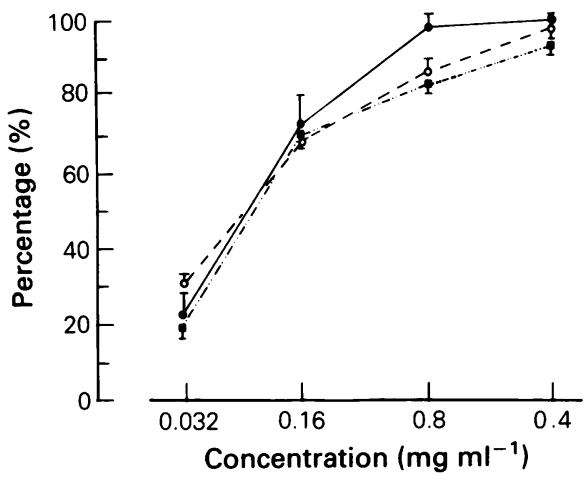

Figure 1 Comparison of cytotoxicity and effect on PBMC proliferation of extract of feverfew. The results show percentage inhibition of PHA (0.03) $\mu \mathrm{g} \mathrm{ml}^{-1}$ )induced proliferation of human PBMC $(\bullet-\bullet)$; inhibition of $L D H$ release as a percentage of total LDH $(0-0)$ and percentage of cells exhibiting trypan blue uptake (-). Organic extracts were evaporated to dryness and re-suspended in PBS giving a final concentration equivalent to $20 \mathrm{mg}$ of powder leaf to $1 \mathrm{ml}$. Similar results were obtained with aqueous extracts and parthenolide. extracts. In the majority of these studies, incubations were performed for no longer than 1 to 2 h. Our own studies would indicate that cytotoxicity would not be evident during a period of a few hours' contact time. However, the finding that the extracts and parthenolide are toxic is not altogether surprising since feverfew is known to be rich in sesquiterpene lactones, particularly parthenolide, which are proven cytotoxic agents affecting fundamental cellular processes (Lee et al., 1970), a fact which is consistent with the somewhat non-specific effects reported for the herb. It is important tc emphasise, however, that the results reported here are from a welldefined in vitro system and the fate of feverfew leaves and any chemical groups therein, ingested, might be different. Furthermore, drugs of known cytotoxicity have been effectively used in RA therapy (Calalresi \& Parks, 1980) and if feverfew is cytotoxic in vivo to lymphocytes or macrophages which are over-active, this could possibly explain the manner in which the herb gives relief to RA sufferers.

Table 2 Cytotoxic effect of crude extracts of feverfew and parthenolide on mitogen-stimulated PBMC

\begin{tabular}{lccc}
\hline & \multicolumn{3}{c}{$\mathrm{LD}_{50}$} \\
& \multicolumn{4}{c}{$24 h$} & $48 h$ & $72 h$ \\
\hline Organic extract $\left(\mathrm{mg} \mathrm{ml}^{-1}\right)$ & $>4.0$ & $2.8 \pm 0.2$ & $0.07 \pm 0.01$ \\
Aqueous extract $\left(\mathrm{mg} \mathrm{ml}^{-1}\right)$ & $>4.0$ & $4.0 \pm 0.6$ & $0.08 \pm 0.01$ \\
Parthenolide & $>1.0 \mathrm{mM}$ & $1.0 \mathrm{mM}$ & $0.012 \pm 0.001 \mu \mathrm{M}$ \\
\hline
\end{tabular}

PBMC $\left(2 \times 10^{5}\right)$ were stimulated with PHA $0.03 \mu \mathrm{g} \mathrm{ml}^{-1}$. Results represent the amounts of substance needed (mg equivalents of leaf $\mathrm{ml}^{-1}$ ) at particular contact times, to cause $50 \%$ cell death, expressed as a percentage of the total LDH released after lysing the cells by freezing and thawing.

\section{References}

Calalresi, P. \& Parks, R. E. Jr. (1980). In The Pharmacological Basis of Therapeutics 6th ed., eds. Goodman, L. S. \& Gilman, A., p. 1261. New York: Macmillan.

Capasso, F. (1986). The effect of an aqueous extract of $T$. parthenium on arachidonic acid metabolism by rat peritoneal leucocytes. J. Pharm. Pharmac., 38, 71-72.

Collier, H. O. J., Butt, N. M., MacDonald-Gibson W. J. \& Sneed S. A. (1980). Extract of feverfew inhibits prostaglandin biosynthesis. Lancet, ii, 922-923.

Gordon, D. \& Lewis, G. P. (1984). Effects of piroxicam on mononuclear cells: comparison with other antiarthritics. Inflammation, 8, 87.

Heptinstall, S., White, A., Williamson, L. \& Mitchell, J. R. A. (1985). Extracts of feverfew inhibit granule secretion in platelets and PMNs. Lancet, ii, 1071-1074.
Lee, H. K., Ranieri, R. L., Towers, G. H. N. \& Lam, J. (1980). Cytotoxicity of sesquiterpene lactones. Cancer Res., 31, 1649-1654.

Lewis, G. P. \& Gordon, D. (1985). Cytokines as potential targets for anti-rheumatic therapy: a pharmacologist's view. Br. J. Rheum., 24, 29-33.

Makheja, A. N. and Bailey, J. M. (1982). A platelet phospholipase inhibitor from the medicinal herb feverfew ( $T$. parthenium). Prostaglandins, Leukotrienes and Medicine, 8, 653-660.

Pickman, A. K.,Huang, E. S., Piantidosi, C., Pagano, J. S. \& Geissman, T. A. (1980). Visualisation reagents for sesquiterpene lactones and polyacetylenes on TLC. J. Chromatog., 189, 187-198.

(Received 14 July 1986, accepted 20 August 1986) 